\title{
Developing a Values Teaching Education Program for Preservice Teachers and Evaluating its Effectiveness
}

\section{Aynur PALA ${ }^{1 \rtimes(D)}$ Derya Göğebakan Yildiz ${ }^{2}$}

1.2Faculty of Education, Manisa Celal Bayar University, Turkey. Email:aynur_pala@yahoo.com Tel: +905326584583

Email:dgogebakan@yahoo.com Tel. +905055703938

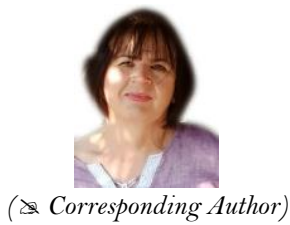

Abstract

The aim of this project was to develop an 8-week values education program and evaluate how well it raises preservice teachers' awareness of values education. This was an experimental and qualitative study conducted in April - May 2019 in eight 70-minute lectures at the Faculty of Education of Manisa Celal Bayar University. An 8-week values education program was developed, then, its effectiveness was evaluated using an experimental pretest-posttest control group design. The sample consisted of 47 students (35 females, 12 males) randomly assigned to two groups: Data were collected using a demographic characteristics form and the Schwartz Value Survey, which consists of 56 values. The values education program was based on eight values derived from the Schwartz Value Survey. A qualitative research method was also used. Data were collected through semi-structured interviews conducted by the researchers. Research results showed that The Values Teaching Educational Program-developed by researchers- had a positive effect on values such as responsibility, social justice, modesty, open-mindedness, protecting environment, honesty, and helpfulness. But it was not found statistically significant difference between control group and experimental group over "successful" value. The qualitative results also show that the values education program met participants' expectations and improved their perceptions and awareness of values and their motivation to put them in practice. Lastly, the values education program helped the experimental participants develop positive views of the program itself and its content, material, activities, duration and the group leader.

Keywords: Schwartz value survey, Preservice teachers, Teachers, Values education program, Values teaching ethics.

Citation | Aynur PALA; Derya Göğebakan Yildiz (2021) Developing a Values Teaching Education Program for Preservice Teachers and Evaluating its Effectiveness. Asian Journal of Education and Training, 7(1): 13-24.

History:

Received: 6 November 2020

Revised: 3 December 2020

Accepted: 23 December 2020

Published: 11 January 2021

Licensed: This work is licensed under a Creative Commons

Attribution 3.0 License $(\mathrm{oc})$ )

Publisher: Asian Online Journal Publishing Group
Acknowledgement: Both authors contributed to the conception and design of the study.

Funding: This study was supported by the Scientific Research Project Office of Manisa Celal Bayar University. Project No: 2019-081.

Competing Interests: The authors declare that they have no conflict of interests.

interests.

Transparency: The authors confirm that the manuscript is an honest, accurate, and transparent account of the study was reported; that no vital features of the study have been omitted; and that any discrepancies from the study as planned have been explained.

Ethical: This study follows all ethical practices during writing.

\section{Contents}

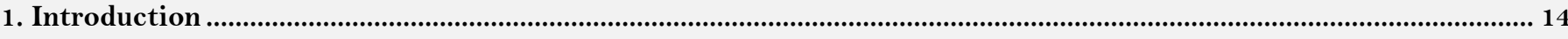

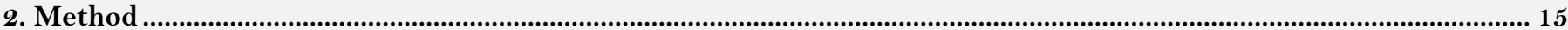

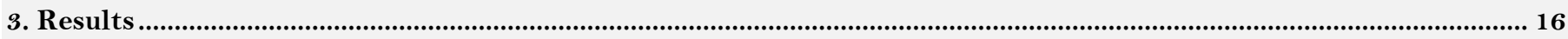

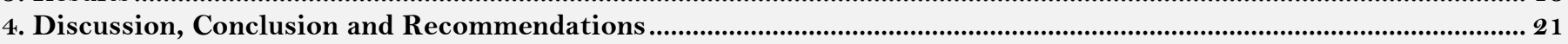

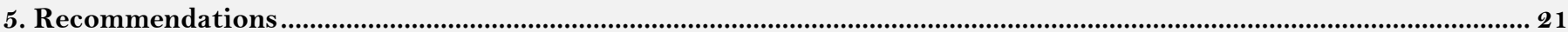

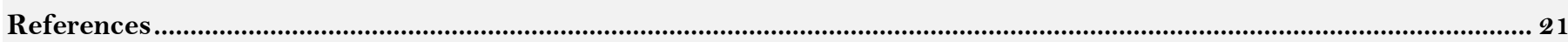




\section{Contribution of this paper to the literature}

In teaching and inculcating values, the teachers have a great role to play. The teachers are expected to advise and guide the pupils regarding their general behaviors in school and outside the school. It has expected that the proposed comprehensive values program suggest some improvements in the existing value education programme and also can raise preservice and teachers' awareness of values and of their roles and they can use it.

\section{Introduction}

Although educators, philosophers, ecclesiastics, researchers, and authors have put forward ideas on the concept of value throughout history, there is no consensus on its definition (Serin \& Buluç, 2014). Approaching the concept of value from a psychological perspective, Allport (1968) associates it with self and defines it as something regarded as desirable and preferable, and worth the commitment and effort to attain or keep it. Rokeach, on the other hand, defines it as certain individual and social ways of conduct and persistent beliefs concerning the purpose of life.

According to Schwartz (1992) values are guiding principles that people use to define themselves, others, and events and to act and justify their actions. Deth and Scarbrough (1998) propose three criteria; a) values cannot be directly observed, b) Values engage moral considerations, and c) Values are conceptions of the desirable. Moral values account for what people consider important to them and others and they encompass not only ways of conduct but also views of the purpose of life.

From the early years of life, people construct value systems, which are influenced first by family, and then by the environment, education, beliefs, and media. What values people hold depends on the structure (nuclear or traditional) and state (broken or united) of the family, the socio-cultural and economic circle they belong to, and the locality in which they live (rural or urban) (Kıran \& Gül, 2016). Although parents seem to be primarily responsible for helping their children develop values, school and society at large should also recognize the shared responsibility and participate in the process. School, in particular, plays a key role in it.

Kuş, Merey, and Karatekin (2013) define values education as a process which provides people with the opportunity to develop moral, human, social, and spiritual values that enable them to focus on development and attaining happiness and peace and connect with one another. Lewis (2007) argues that values education promotes academic performance and provides a peaceful educational environment. It also helps students develop communication, critical thinking, self-management, and self-awareness skills.

According to Deth and Scarbrough (1998) values education is based on universal values accepted by everyone and is also a national movement that helps schools provide young people with good role models to set an example of thinking styles and behaviors needed to grow to be sensitive, moral, and responsible people with good personality traits. Values education is a slow-paced process that cultivates not only the mind, but also the heart. It involves practices implemented by schools, regions, and states to teach children and young people basic human values (respect and consideration for themselves and others, honesty, justice, responsibility, morality, kindness, generosity, courage, freedom, self-discipline, equality, etc.) and how to put them in practice.

According to Lickona (1991) character education plays a critical role in reaching three main goals: 1) being a mature person, 2) attaining family relationships based on love and mutual respect, and 3) contributing to society. In this context, the goal of values education is to be an integral part of school culture, and thereby fostering social, moral, and academic growth and helping students internalize the moral values of respect, responsibility, honesty, justice compassion etc. and act in line with those values. Values education plays a key role in transforming students into moral and productive members of society (O'Sullivan, 2004). The students of today should be not only academically sound but also collaborative, hardworking, and honest, for they will be the leaders of tomorrow who will make a difference not only in their own communities but also in the whole world.

Social, ethical, and affective development is as important as academic performance. Therefore, schools should be designed in such a way that they can both promote learning and encourage students to develop moral values. Schools with values education are more likely to have students with high readiness to learn and have teachers with high self-confidence in their own teaching. Teachers state that values education results in fewer discipline and behavioral problems and more time to teach (Lickona, 1991).

Therefore, children should be introduced at an early age to values education, for which especially education faculty teachers and preservice teachers are responsible. Teachers of the future should be aware of themselves, of the society in which they live, and of universal values which surround them, and know what values to teach. Therefore, preservice teachers should be offered activities to help them learn about and internalize moral values so that they can teach them to the younger generations. Preservice teachers who get to learn moral values and develop skills through values education activities are more likely to apply them to their personal and professional lives and exponentially promote healthy youth and healthy society. At this point, the critical factor is the teachers and the programs used to train them. It is of paramount importance to offer preservice teachers with values education to make sure that values can be passed down to younger generations.

Some studies in Turkey address preservice teachers' views of values (Bacanll, 1999; Sarıcı, 2013; Yapıcı, Kutlu, $\&$ Bilican, 2012). However, there are no effective programs that can be used to make students more sensitive to values. The aim of this study was, therefore, to develop a comprehensive and effective values education program (VEP) for all preservice teachers. The relevant literature was used to develop a VEP. We believe that educators can use the proposed program to raise preservice teachers' awareness of values and of their roles.

This study offered an eight-session training program for the values of "responsibility" (being reliable and dependable), "social justice" (correcting injustices, caring for the weak), "modesty" (), "open-mindedness" (tolerance and respect for different opinions and beliefs), "protecting the environment" (conserving nature), "honesty" (sincerity), "success" (reaching goals), and "helpfulness" (acting for the welfare of others) first to raise preservice teachers' awareness of values and then to provide them with a road map on how to teach those values to their students in order to increase the number of people who adhere to universal values in their individual and collective actions.

The study sought answers to the following questions: 
1- Do preservice teachers who have participated in VEP have a significantly higher posttest "Schwartz Value Survey" score than those who have not?

2- What do preservice teachers who have participated in VEP think about it?

\section{Method}

\subsection{Research Method}

This study employed a mixed methods design involving both quantitative and qualitative data collection and analysis (Creswell, 2003). The effectiveness of VEP was evaluated using an experimental pretest-posttest control group design (Büyüköztürk, Kılıç, Akgün, Karadeniz, \& Demirel, 2011). Quantitative data were collected using the Schwartz Value Survey, while qualitative data were collected through interviews.

\subsection{Sample}

At the beginning of April 2019, students were informed about VEP, and about its content and terms of participation. The sample consisted of 47 (35 females and 12 males) students who enrolled in the departments of Primary Teacher Training, Turkish Teacher Training, Mathematics Teacher Training and Psychological Counseling and Guidance. Students were assigned numbers (S1, S2, S3, etc.) to ensure confidentiality and were randomized into an experimental $(n=24)$ or a control $(n=23)$ group.2.3.

\subsection{Data Collection Tools}

Data were collected using a demographic characteristics form, a values education program interview form, and the Schwartz Value Survey.

\subsection{Demographic Characteristics Form}

The demographic characteristics form (Appendix 1), developed by the researchers consisted of items on gender, age, grade level, major, and place of residence.

\subsection{Schwartz Value Survey}

The Schwartz Value Survey (SVS) was developed by Schwartz (1992) and adapted to Turkish by Kagitcibasi and Kuşdil (2000). The SVS consists of 56 value items VEP in this study consisted of eight values derived from the SVS: (1) responsibility (being reliable and dependable), (2) social justice (correcting injustices, caring for the weak), (3) modesty (avoiding extremes of feeling and action), (4) open-mindedness (tolerance and respect for different opinions and beliefs), (5) protecting the environment (conserving nature), (6) honesty (sincerity), (7) success (reaching goals), and (8) helpfulness (acting for the welfare of others).

\subsection{Interview Form}

After the VEP intervention, participants were interviewed using the following questions:

\subsection{Values Education Program Interview Form}

1. What did you expect of VEP? Did it meet your expectations?

2. Did VEP help you improve yourself? If so, in what way?

3. How would you evaluate the content, materials, activities, duration, and group leader of VEP?

\subsection{Procedure}

The goal of the 8-week VEP was to raise preservice teachers' awareness of values and then provide them with a road map on how to teach those values to their students in order to increase the number of people who adhere to universal values in their individual and collective actions. The following are the steps of developing VEP.

\subsection{Developing VEP}

VEP was developed in four steps: a. Literature review, b. Drawing up a draft, c. Consulting with experts d. Conducting a pilot test

\subsection{VEP Themes}

VEP was an eight-session program consisting of themes based on university students' developmental level and needs. Table 1 shows the VEP themes.

\begin{tabular}{l|l}
\hline Sessions & Themes \\
\hline Session One & Responsibility (being reliable and dependable) \\
\hline Session Two & Social justice (correcting injustices, caring for the weak) \\
\hline Session Three & Modesty (avoiding extremes of feeling and action) \\
\hline Session Four & Open-mindedness (tolerance and respect for different opinions and beliefs) \\
\hline Session Five & Protecting the environment (conserving nature) \\
\hline Session Six & Honesty (sincerity) \\
\hline Session Seven & Success (reaching goals) \\
\hline Session Eight & Helpfulness (acting for the welfare of others) \\
\hline
\end{tabular}

Studies on effective training programs were evaluated to outline the content of the sessions. The sessions consisted of methods facilitating active engagement and self-expression, and involving activities and interactive teaching techniques that allow participants to discuss current values. Appendix 1 presents the details of the goals, content, learning activities and evaluation processes of the sessions 
Two academics from the departments of the Psychological Counseling and Guidance and Curriculum and Instruction were consulted concerning the VEP draft, which was then revised based on their feedback. A onesession pilot study was conducted with seven preservice teachers, and VEP was finalized based on the results.

\subsection{1.. Data Analysis}

The quantitative data were analyzed using descriptive analysis, $t$ test, and ANOVA, while the qualitative data were analyzed using descriptive analysis.

\section{Results}

This section addressed the quantitative and qualitative results.

3.1. Results regarding the First Research Question

The first research question addressed whether the experimental group (VEP) had a significantly higher posttest SVS score than the control group. Table 2 shows the results.

Table-2. T-test results of SVS scores of experimental and control groups.

\begin{tabular}{|c|c|c|c|c|c|c|c|}
\hline Values & Group & $\mathbf{N}$ & Mean & SS & $\mathbf{t}$ & Sd & p \\
\hline \multirow[t]{2}{*}{ Responsibility } & Experimental & 24 & 4.42 & 1.66 & \multirow[t]{2}{*}{.052} & \multirow[t]{2}{*}{45} & \multirow[t]{2}{*}{.959} \\
\hline & Control & 23 & 4.39 & 1.67 & & & \\
\hline \multirow[b]{2}{*}{ Social justice } & Experimental & 24 & 4.95 & 1.92 & & & \\
\hline & Control & 23 & 5.13 & 1.76 & -.319 & 45 & .751 \\
\hline \multirow[b]{2}{*}{ Modesty } & Experimental & 24 & 3.00 & 2.18 & & & \\
\hline & Control & 23 & 3.87 & 2.07 & -1.398 & 45 & 169 \\
\hline \multirow[b]{2}{*}{ Open-mindedness } & Experimental & 24 & 4.29 & 1,92 & & & \\
\hline & Control & 23 & 4.30 & 1.82 & -.023 & 45 & .982 \\
\hline \multirow[t]{2}{*}{ Protecting the environment } & Experimental & 24 & 4.50 & 2.04 & & & \\
\hline & Control & 23 & 4.56 & 1.90 & -.113 & 45 & .910 \\
\hline \multirow[b]{2}{*}{ Honesty } & Experimental & 24 & 4.87 & 1.80 & & & \\
\hline & Control & 23 & 5.56 & 1.70 & -1.349 & 45 & .184 \\
\hline \multirow{2}{*}{ Success } & Experimental & 24 & 4.04 & 1.98 & & & \\
\hline & Control & 23 & 4.26 & 1.95 & -.381 & 45 & .705 \\
\hline \multirow[t]{2}{*}{ Helpfulness } & Experimental & 24 & 3.75 & 2.11 & & & \\
\hline & Control & 23 & 4.65 & 1.58 & -1.651 & 45 & .106 \\
\hline
\end{tabular}

The There was no statistically significant difference in pretest SVS subscale scores between the experimental and control groups $(t=.052 ;-.319 ;-1.398 ;-.023 ;-.113 ;-1.349 ;-.381 ;-1.651 ; p>.05)$ (Table 2$)$, suggesting that all participants had similar value orientations before the VEP intervention.

\subsection{Group-Measurement Effect concerning the Value of Responsibility}

Tables 3 and IV show, respectively, the descriptive statistics and two-way ANOVA results concerning the VEP participants' orientation to the value of "responsibility."

Table-3. Experimental and Control Group Pretest-Posttest Descriptive Statistics concerning the Value of Responsibility

\begin{tabular}{l|l|c|c|c}
\hline Measurement & Group & $\boldsymbol{N}$ & Mean & SS \\
\hline \multirow{2}{*}{ Pre-test } & Experimental & 24 & 4.42 & 1.66 \\
\cline { 2 - 5 } & Control & 23 & 4.39 & 1.67 \\
\hline \multirow{2}{*}{ Post-test } & Experimental & 24 & 5.83 & 1.10 \\
\cline { 2 - 5 } & Control & 23 & 4.56 & 1.59 \\
\hline
\end{tabular}

Table-4. Two-way ANOVA results concerning the value of responsibility.

\begin{tabular}{|c|c|c|c|c|c|c|}
\hline Source of Variance & $\mathbf{S S}$ & sd & MS & $\mathbf{F}$ & $\mathbf{p}$ & $\eta 2$ \\
\hline \multicolumn{7}{|l|}{ Between groups } \\
\hline $\begin{array}{l}\text { Group (Experimental and } \\
\text { Control) }\end{array}$ & 9.825 & 1 & 9.825 & 2.47 & .123 & .05 \\
\hline \multicolumn{7}{|l|}{ Within groups } \\
\hline $\begin{array}{l}\text { Measurement (Pre-test-post- } \\
\text { test) }\end{array}$ & 14.857 & 1 & 14.857 & 22.61 & .000 & .33 \\
\hline Group*Measurement & 9.069 & 1 & 14.857 & 13.803 & .001 & .24 \\
\hline
\end{tabular}

The two-way ANOVA (two groups $\mathrm{X}$ two measurements) analysis showed that Measurement and Group*Measurement resulted in a statistically significant difference between pretest and posttest SVS "responsibility" subscale scores across the two groups $\left[\mathrm{F}(\mathrm{M})=22.61, \mathrm{p}=0.000<0.05 ; \mathrm{F}\left(\mathrm{G}^{*} \mathrm{M}\right)=13.803, \mathrm{p}=0.001\right.$ $<0.05]$.

The post-hoc test results showed that the experimental group had significantly higher posttest SVS "responsibility" subscale scores than the control group $(\mathrm{p}<0.05)$ (Tables 3 and 4$)$. 
3.3. Group-Measurement Effect concerning the Value of Social Justice

Table-5. Experimental and Control Group Pretest-Posttest Descriptive Statistics concerning the Value of Social Justice.

\begin{tabular}{l|c|c|c|c}
\hline Measurement & Group & N & Mean & SS \\
\hline \multirow{2}{*}{ Pre-test } & Experimental & 24 & 4.95 & 1.92 \\
\cline { 2 - 5 } & Control & 23 & 5.13 & 1.76 \\
\hline \multirow{2}{*}{ Post-test } & Experimental & 24 & 6.08 & 1.28 \\
\cline { 2 - 5 } & Control & 23 & 5.34 & 1.40 \\
\hline
\end{tabular}

Table-6. Two-way ANOVA results concerning the value of social justice.

\begin{tabular}{|c|c|c|c|c|c|c|}
\hline Source of Variance & SS & sd & MS & $\mathbf{F}$ & $\mathbf{p}$ & $\eta 2$ \\
\hline \multicolumn{7}{|l|}{ Between groups } \\
\hline Group (Experimental and Control ) & 1.864 & 1 & 1.864 & .419 & .521 & .009 \\
\hline \multicolumn{7}{|l|}{ Within groups } \\
\hline Measurement(Pre-test-post-test) & 10.582 & 1 & 10.582 & 13.896 & .001 & .236 \\
\hline Group*Measurement & 4.837 & 1 & 4.837 & 6.352 & .015 & .124 \\
\hline
\end{tabular}

The two-way ANOVA (two groups $\mathrm{X}$ two measurements) analysis showed that Measurement and Group*Measurement resulted in a statistically significant difference between pretest and posttest SVS "social justice" subscale scores across the two groups $[\mathrm{F}(\mathrm{M})=13.896, \mathrm{p}=0.001<0.05 ; \mathrm{F}(\mathrm{G} * \mathrm{M})=6.352, \mathrm{p}=0.015<0.05]$. The post-hoc test results showed that the experimental group had significantly higher posttest SVS "social justice" subscale scores than the control group $(\mathrm{p}<0.05)$ (Tables 5 and 6 ).

\subsection{Group-Measurement Effect concerning the Value of Modesty}

Table-7. Experimental and control group pretest-posttest descriptive statistics concerning the value of modesty.

\begin{tabular}{c|c|c|c|c}
\hline Measurement & Group & N & Mean & SS \\
\hline \multirow{2}{*}{ Pre-test } & Experimental & 24 & 3.00 & 2.18 \\
\cline { 2 - 5 } & Control & 23 & 3.86 & 2.07 \\
\hline \multirow{2}{*}{ Post-test } & Experimental & 24 & 4.87 & 1.73 \\
\cline { 2 - 5 } & Control & 23 & 3.52 & 1.85 \\
\hline
\end{tabular}

Table-8. Two-way ANOVA results concerning the value of modesty.

\begin{tabular}{l|c|c|c|c|c|c}
\hline Source of Variance & SS & sd & MS & F & p & ๆ2 \\
\hline Between groups & & & & & & \\
\hline Group (Experimental and Control) & 1.374 & 1 & 1.374 & .211 & .648 & .005 \\
\hline Within groups & & & & & & \\
\hline Measurement (Pre-test-post-test) & 13.696 & 1 & 13.696 & 11.021 & .002 & .197 \\
\hline Group*Measurement & 29.015 & 1 & 29.015 & 23.348 & .000 & .342 \\
\hline
\end{tabular}

The two-way ANOVA (two groups X two measurements) analysis showed that Measurement and Group*Measurement resulted in a statistically significant difference between pretest and posttest SVS "modesty" subscale scores across the two groups $[\mathrm{F}(\mathrm{M})=11.021, \mathrm{p}=0.002<0.05 ; \mathrm{F}(\mathrm{G} * \mathrm{M})=23.348$, $\mathrm{p}=0.000<0.05]$. The posthoc test results showed that the experimental group had significantly higher posttest SVS "modesty" subscale scores than the control group $(\mathrm{p}<0.05)$ (Tables 7 and 8 ).

\subsection{Group-Measurement Effect concerning the Value of Open-mindedness}

Table-9. Experimental and control group pretest-posttest descriptive statistics concerning the value of being open-minded.

\begin{tabular}{l|c|c|c|c}
\hline Measurement & Group & N & Mean & SS \\
\hline \multirow{2}{*}{ Pretest } & Experimental & 24 & 4.29 & 1.92 \\
\cline { 2 - 5 } & Control & 23 & 4.30 & 1.81 \\
\hline \multirow{2}{*}{ Posttest } & Experimental & 24 & 5.50 & 1.35 \\
\cline { 2 - 5 } & Control & 23 & 4.52 & 1.83 \\
\hline
\end{tabular}

Table-10. Two-way ANOVA Results concerning the Value of Open-mindedness.

\begin{tabular}{l|c|c|c|c|c|c}
\hline Source of Variance & SS & sd & MS & F & p & ๆ2 \\
\hline Between groups & & & & & & \\
\hline Group (Experimental and Control) & 5.475 & 1 & 5.475 & 1.050 & .311 & .023 \\
\hline Within groups & & & & & & \\
\hline Measurement (Pre-test-post-test) & 11.937 & 1 & 11.937 & 13.796 & .001 & .235 \\
\hline Group*Measurement & 5.766 & 1 & 5.766 & 6.665 & .013 & .129 \\
\hline
\end{tabular}

The two-way ANOVA (two groups X two measurements) analysis showed that Measurement and Group*Measurement resulted in a statistically significant difference between pretest and posttest SVS "openmindedness" subscale scores across the two groups $[\mathrm{F}(\mathrm{M})=13.796, \mathrm{p}=0.001<0.05 ; \mathrm{F}(\mathrm{G} * \mathrm{M})=6.665, \mathrm{p}=0.013$ $<0.05]$. The post-hoc test results showed that the experimental group had significantly higher posttest SVS “openmindedness" subscale scores than the control group $(\mathrm{p}<0.05)$ (Tables 7 and 8). 
3.6. Group-Measurement Effect concerning the Value of Protecting the Environment

Table-11. Experimental and control group pretest-posttest descriptive statistics concerning the value of protecting the environment.

\begin{tabular}{c|c|c|c|c}
\hline Measurement & Group & N & Mean & SS \\
\hline \multirow{2}{*}{ Pre-test } & Experimental & 24 & 4.50 & 2.04 \\
\cline { 2 - 5 } & Control & 23 & 4.56 & 1.90 \\
\hline \multirow{2}{*}{ Post-test } & Experimental & 23 & 6.04 & 1.39 \\
\cline { 2 - 5 } & Control & 23 & 4.73 & 1.71 \\
\hline
\end{tabular}

Table-12. Two-way ANOVA results concerning the value of protecting the environment.

\begin{tabular}{|c|c|c|c|c|c|c|}
\hline Source of Variance & $\mathbf{S S}$ & sd & MS & $\bar{F}$ & $\bar{p}$ & $\eta 2$ \\
\hline \multicolumn{7}{|l|}{ Between groups } \\
\hline Group (Experimental and Control) & 8.990 & 1 & 8.990 & 1.756 & .192 & .038 \\
\hline \multicolumn{7}{|l|}{ Within groups } \\
\hline Measurement (Pre-test-post-test) & 17.284 & 1 & 17.284 & 14.237 & .000 & .240 \\
\hline Group*Measurement & 10.986 & 1 & 10.986 & 9.049 & .004 & .167 \\
\hline
\end{tabular}

The two-way ANOVA (two groups $\mathrm{X}$ two measurements) analysis showed that Measurement and Group*Measurement resulted in a statistically significant difference between pretest and posttest SVS "protecting the environment" subscale scores across the two groups $[\mathrm{F}(\mathrm{M})=14.237, \mathrm{p}=0.000<0.05 ; \mathrm{F}(\mathrm{G} * \mathrm{M})=9.049$, $\mathrm{p}=0.004$ $<0.05]$. The post-hoc test results showed that the experimental group had significantly higher posttest SVS "protecting the environment" subscale scores than the control group ( $\mathrm{p}<0.05)$ (Tables 11 and 12).

\subsection{Group-Measurement Effect concerning the Value of Honesty}

\begin{tabular}{l|c|c|c|c} 
Table -13. Experimental and Control Group Pretest-Posttest Descriptive Statistics concerning the Value of Honesty. \\
\hline Measurement & Group & N & Mean & SS \\
\hline \multirow{2}{*}{ Pre-test } & Experimental & 24 & 4.87 & 1.80 \\
\cline { 2 - 5 } & Control & 23 & 5.56 & 1.70 \\
\hline Post-test & Experimental & 24 & 6.03 & .95 \\
\cline { 2 - 5 } & Control & 23 & 5.47 & 1.67 \\
\hline
\end{tabular}

Table-14. Two-way ANOVA results concerning the value of honesty.

\begin{tabular}{|c|c|c|c|c|c|c|}
\hline Source of Variance & $\overline{\text { SS }}$ & sd & $\overline{M S}$ & $\mathbf{F}$ & $\bar{p}$ & $\eta 2$ \\
\hline Between groups & & & & & & \\
\hline Group (Experimental and Control ) & .094 & 1 & .094 & .024 & .877 & .001 \\
\hline Within groups & & & & & & \\
\hline Measurement (Pre-test-post-test) & 6.846 & 1 & 6.846 & 6.910 & .012 & .133 \\
\hline
\end{tabular}

The two-way ANOVA (two groups $\mathrm{X}$ two measurements) analysis showed that Measurement and Group*Measurement resulted in a statistically significant difference between pre-test and post-test SVS "honesty" subscale scores across the two groups $[\mathrm{F}(\mathrm{M})=6.910, \mathrm{p}=0.012<0.05 ; \mathrm{F}(\mathrm{G} * \mathrm{M})=9.316$, $\mathrm{p}=0.004<0.05]$. The post-hoc test results showed that the experimental group had significantly higher post-test SVS "honesty" subscale scores than the control group ( $\mathrm{p}<0.05)$ (Tables 11 and 12).

\subsection{Group-Measurement Effect concerning the Value of Success}

\begin{tabular}{l|c|c|c|c} 
Table-15. Experimental and Control Group Pre-test-Post-test Descriptive Statistics concerning the Value of Success. \\
\hline Measurement & Group & N & Mean & SS \\
\hline \multirow{2}{*}{ Pre-test } & Experimental & 24 & 4.04 & 1.98 \\
\cline { 2 - 5 } & Control & 23 & 4.26 & 1.95 \\
\hline Post-test & Experimental & 24 & 4.70 & 1.68 \\
\cline { 2 - 5 } & Control & 23 & 4.73 & 1.68 \\
\hline
\end{tabular}

Table-16. Two-way ANOVA results concerning the value of success.
\begin{tabular}{l|l|l|l|l|l|l}
\hline Source of Variance & SS & sd & MS & F & p & $\mathbf{\eta 2}$ \\
\hline Between groups & & & & & & \\
\hline Group (Experimental and Control) & .367 & 1 & .367 & .060 & .808 & .001 \\
\hline Within groups & & & & & & \\
\hline Measurement (Pre-test-post-test) & 7.698 & 1 & 7.698 & 13.054 & .001 & .225 \\
\hline Group*Measurement & .208 & 1 & .208 & .353 & .555 & .008 \\
\hline
\end{tabular}

The two-way ANOVA (two groups X two measurements) analysis showed that Group*Measurement did not result in a statistically significant difference between pretest and posttest SVS "success" subscale scores across the two groups $\left[\mathrm{F}(\mathrm{M})=13.054, \mathrm{p}=0.001<0.05 ; \mathrm{F}\left(\mathrm{G}^{*} \mathrm{M}\right)=.353, \mathrm{p}=0.555>0.05\right]$ (Tables 15 and 16 ). 
3.9. Group-Measurement Effect Concerning the Value of Helpfulness

Table-17. Experimental and Control Group Pretest-Posttest Descriptive Statistics concerning the Value of Helpfulness

\begin{tabular}{c|c|c|c|c}
\hline Measurement & Group & N & Mean & SS \\
\hline \multirow{2}{*}{ Pre--test } & Experimental & 24 & 3.75 & 2.11 \\
\cline { 2 - 5 } & Control & 23 & 4.65 & 1.58 \\
\hline \multirow{2}{*}{ Post-test } & Experimental & 24 & 5.62 & 1.10 \\
\cline { 2 - 5 } & Control & 23 & 4.21 & 1.83 \\
\hline
\end{tabular}

\begin{tabular}{|c|c|c|c|c|c|c|}
\hline Source of Variance & SS & sd & MS & $\mathbf{F}$ & $\mathbf{p}$ & $\eta 2$ \\
\hline \multicolumn{7}{|l|}{ Between groups } \\
\hline Group (Experimental and Control) & 1.500 & 1 & 1.500 & .318 & .575 & .007 \\
\hline \multicolumn{7}{|l|}{ Within groups } \\
\hline Measurement (Pre-test-post-test) & 12.181 & 1 & 12.181 & 11.628 & .001 & .205 \\
\hline Group*Measurement & 31.329 & 1 & 31.329 & 29.908 & .000 & .399 \\
\hline
\end{tabular}

The two-way ANOVA (two groups $\mathrm{X}$ two measurements) analysis showed that Measurement and Group*Measurement resulted in a statistically significant difference between pretest and posttest SVS "helpfulness" subscale scores across the two groups $[\mathrm{F}(\mathrm{M})=11.628, \mathrm{p}=0.001<0.05 ; \mathrm{F}(\mathrm{G} * \mathrm{M})=29.908, \mathrm{p}=0.000$ $<0.05]$. The post-hoc test results showed that the experimental group had significantly higher posttest SVS "helpfulness" subscale scores than the control group $(\mathrm{p}<0.05)$ (Tables 17 and 18).

\subsection{Results Regarding the Second Research Question}

This section addressed the interviews results.

1. What did you expect of VEP? Did it meet your expectations?

2. Did VEP help you improve yourself? If so, in what way?

3. How would you evaluate the content, materials, activities, duration, and group leader of VEP?

\subsection{What Did You Expect of VEP? How satisfied are you with it?}

The first interview question was "What did you expect of VEP? Did it meet your expectations?" All participants stated that VEP met their expectations. The following are direct quotations from participants:

\subsubsection{Participants with Expectations of Personal Development} 12).

My expectation was to become more sensitive and aware, so I think that VEP helped me with that. (Student (S)

I expected VEP to let me fill gaps in my knowledge, and it mostly did that (S24).

My expectation was that I would learn new things and become more aware of things, and it mostly did that. It was nice that they held such an activity in college. I mean, responsibility, treating everyone equally, respecting different ideas, being non-judgmental and helpful, and acting for the welfare of others were very nice feelings. I was very happy to get that training.) (S15).

\subsubsection{Participants Expecting to Improve Teaching Skills}

I'm soon to be a primary school teacher, and so I took part in VEP because I thought I had to, and it was like what I expected it to be. I believe that I'll use the things I've learned in my profession life and that I'll put them in practice throughout my life. (S6).

As a preservice teacher, I think that we should definitely get that kind of training. I can say that it's taught me things and helped me do some insight and recognize my own mistakes. (S22)

\subsection{3. Participants with Very Low Expectations}

I thought VEP was going to be more about boring and simple subjects, but I must say I was wrong. I took part in all eight sessions and none of them was boring. It even got more interesting with the examples given by the teacher. (S3)

I had no expectations at all, I mean, I thought that the teacher was going to show up and talk about some stuff from the book, but it was impressive that the leader did some connections with everyday life, which was very relatable and transferrable to my life $(\mathrm{S} 4)$.

\subsubsection{Participants Who Stated that VEP Exceeded their Expectations}

I thought it was going to be like sessions where we would exchange ideas and discuss about some things under specific headings, but it was actually more than I expected. I got to see my own strengths and weaknesses about the issues we discussed and got to exchange opinions with like-minded or not-like-minded people, so I believe that that atmosphere helped me a lot to improve myself. (S13).

At first, I thought it was going to be boring, it was nothing like that. I was very active, and I wanted to keep talking about my experience. (S17).

\subsubsection{A Participant Stated that She Found Educational Activities Based on Voluntary Participation without Grading Much More Effective:}

To be honest, at first I didn't know what it was all about, but good thing I took part in it. I enjoy educational activities with no grading because voluntary participation made the activity more meaningful. (S10) 


\subsection{6. Did VEP Help You Improve Yourself? In What Way?}

The second interview question was "Did VEP help you improve yourself? If so, in what way?" All participants stated that they found VEP successful. They became more aware and sensitive to the values addressed by VEP.

The following are direct quotations from participants:

\subsubsection{Participants talking about the Contributions that VEP has Made to their Intellectual Capacity}

Yes, it did. I got the chance to think about my take on things that we talked about during VEP, and I mulled over and voiced my own thoughts about them. (S10).

VEP got me to exchange ideas and hear different opinions, which broadened my horizon and learn more about things and talk more about them. (S17).

It's changed my perspective. I asked myself questions like, "I am eco-friendly enough?" or "Am I openminded?" or "How important is honesty to me?" and I answered them and gave them some thought and came up with new ideas, so I believe it's helped me improve myself. (S13).

\subsection{Participants Talking about how they put VEP Subjects into Practice}

I think VEP helped me better understand the concept of social justice, and I believe I've had some progress when it comes to people that are close to me. In the "Protecting the Environment" course, I came to realize that it's not only about protecting the environment but it's about understanding what nature is all about while protecting it, and so I put some effort into it. I do more recycling in the dorm. I used to enjoy taking long showers but now I make sure that it's not longer than five minutes. (S6).

Now I think twice before I dump things in the garbage. Another thing that has changed in my life is that when someone talks about his problems, I avoid giving examples from my own life and instead try to offer solutions. (S18).

Now I think deeply about even the most trivial things. I've come to realize that even the most trivial things might be very important. I've conquered my fears. I used to be afraid of dogs, I mean I was not a big fan of them, but now I walk up to them and give them water in these hot days. I approach people without any preconceived notions about them and I try to get to know them. (S21).

\subsubsection{A Participant who Stated that VEP Contributed to Parenting Skills}

I will be a parent in the future, so I think I should know about these values. (S9).

\subsubsection{A Participant Expressing the Changes in her Inner world}

VEP has helped me a lot, it's helped me to stop and think, like doing self-evaluation and self-recognition. When I put my head on the pillow at night or at the end of a training day, it got me to think that I should think about what I did for the training and what good it did to me. I'm thinking it's a good thing that I had that training [VEP] (S14).

\subsubsection{Some Participants Stated that VEP Helped them fill the Gaps in their Knowledge}

VEP has been effective because it's helped me see the blind spots in my knowledge and express my thoughts openly. (S16).

We did some comprehensive learning about values. I learned that values actually have different dimensions. I felt incompetent in some values, and so I improved myself about them. (S19).

VEP made me a little more aware of things. I saw that I was incompetent in some issues. I learned new things about values. (S20).

\subsubsection{How Would You Evaluate the Content, Materials, Activities, Duration, and Group Leadership of VEP?}

The third interview question was "How would you evaluate the content, materials, activities, duration, and group leadership of VEP?" All participants had positive views of the content, materials, activities, duration, and group leadership of VEP. The following are direct quotations from participants:

Almost all participants found the content of VEP adequate and appropriate.

VEP had good content, it was very relatable and addressed things we should pay attention to $(\mathrm{S} 1)$.

VEP addressed meaningful and must-have topics from a wide perspective. It had rich content because it was all about life. (S4).

It had good content addressing values that concern social life. (S7).

I think the topics of VEP were very nice. Of all the core values, it addressed the ones that need to be put into practice and are most worth talking about.

\subsubsection{Participants had Positive Views of the VEP Activities and Materials}

I think that the materials did the best they could to help me with the topics. They sometimes kept us focused and sometimes helped us develop new perspectives. The activities engaged all students in learning. (S11).

The videos and stories were full of useful examples that helped us better understand things. (S18).

Sessions, slides, videos, surveys, stories ... The group leader presented the topics, which are as important as they are classic, in a pleasant and entertaining discussion environment, resulting in learning retention. (S17).

\subsubsection{Most Participants Found the Duration of VEP Sufficient}

I think it was long enough. The group leader let everyone talk and gave examples from his own life, so I got the chance to hear what my classmates thought about things and to compare with my own (S21)

The sessions were about 70 to 80 minutes, I think it was long enough to address the topics, I mean, it was quite ideal, neither too short nor too long. (S19)

The sessions were long enough, but we could have talked more if they had been longer, though. (S3) 


\subsubsection{Participants Had Positive Views of the Group Leader.}

The group leader was very open, she gave examples from her own life. (S12).

The teacher gave the best examples to help us better understand the topics. Her examples were very nice and thought-provoking. (S22).

The group leader let us all talk and gave examples from her own life. We got to compare her experiences to ours. (S21).

The teacher was always ready and willing to do class, she always showed up with notes in her hand, which gave us positive energy. (S14).

I think that the group leader possesses all the values she taught us and I think that she is very good at teaching what she knows.

The group leader was always ready to teach and always showed up with teaching materials. She knew very well what she was teaching. ( $\mathrm{S} 1)$.

\section{Discussion, Conclusion and Recommendations}

The main goal of this study was to develop and implement an 8-week values education program (VEP) to improve preservice teachers' orientation to values and to evaluate its effectiveness. The sub goals of the study were to determine what all participants thought about VEP and whether the VEP group had significantly higher SVS scores than controls.

The 8-week VEP helped the experimental participants improve responsibility (being reliable and dependable), social justice (correcting injustices, caring for the weak), modesty (avoiding extremes of feeling and action), openmindedness (tolerance and respect for different opinions and beliefs), protecting the environment (conserving nature), honesty (sincerity), and helpfulness (acting for the welfare of others) values. However, there was no significant difference in SVS success (reaching goals) scores between the two groups.

Research shows that most values education programs are successful (Finck, Hansen, \& Jensen, 2003; Ozyurt, Demir, \& Bay, 2015; Uysal, 2008). For example, Berkowitz and Bier (2005, in Ozyurt et al. (2015) conducted a meta-analysis on the effectiveness of 39 character/values education programs and concluded that thirty-three of them are effective. Uysal (2008) also concluded that most VEPs are effective on students.

There was no significant difference in SVS success (reaching goals) scores between the two groups. According to Erikson's theory of psychosocial development, school age, referred to as second childhood, is the developmental stage where people develop the value of success. Therefore, what preservice teachers experience during that period should be investigated. It is also widely accepted that character education in schools is associated with academic performance. Benninga, Berkowitz, Kuehn, and Smith (2003) investigated the effectiveness of character education in primary schools in California and reported that the program improved students' academic performance. In conclusion, VEP in early school years is much more effective in value development.

The first interview question was "What did you expect of VEP? Did it meet your expectations?" All participants stated that VEP met their expectations, indicating that the design of VEP satisfies preservice teachers' expectations.

Interviews were conducted with participants after the VEP intervention to obtain qualitative results. The second interview question was "Did VEP help you improve yourself? If so, in what way?" All participants stated that VEP made them more aware and sensitive to the values it addressed.

The third interview question was "How would you evaluate the content, materials, activities, duration, and group leadership of VEP?" All participants had positive views of the VEP content, materials, activities, duration, and group leader. According to their statements, VEP is neither too long or too short and has fun and informative activities and adequate materials that are compatible with the activities; the group leader planned and conducted the activities very well and managed the process effectively.

Most studies on values education focus on preservice teachers' orientation to moral values and their views of those values and values education (Mercader, 2006; Pala \& Göğebakan, 2019; Sarı, 2005). However, there are also some studies investigating the effectiveness of VEPs designed for preservice teachers. For example, Kılcan (2016) reported that a "Values Education" course improved preservice teachers' views of values and their teaching. Our results show that the 8-week VEP can help preservice teachers develop values and teach them to their students in the future

In conclusion, the 8-week VEP helps preservice teachers develop positive attitudes towards values and raises their awareness of them and makes them motivated to put them in practice. It also provide them with a road map on how to teach those values to their students in the future. Therefore, education faculties should offer VEPs as a course.

\section{Recommendations}

1) All departments of education faculties should offer values courses.

2) VEPs should be complemented with extracurricular activities.

3) Administrators, teachers, and parents should always take into consideration the effect of attitudes towards school, values education, and motivation for success on academic performance. Therefore, related conferences, workshops, and seminars as well as program activities should be organized.

\section{References}

Allport, G. W. (1968). The Person in psychology. Boston, MA: Beacon Press.

Bacanl, H. (1999). Value preferences of university students. Educational Administration: Theory and Practice, 5(20), 597-610.

Benninga, J. S., Berkowitz, M. W., Kuehn, P., \& Smith, K. (2003). The relationship of character education implementation and academic achievement in elementary schools. Journal of Research in Character Education, 1(1), 19-32.

Büyüköztürk, Ş., Kılıç, Ç. E., Akgün, Ö. E., Karadeniz, E., \& Demirel, F. (2011). Scientific research methods. Ankara: Pegem A Publishing.

Creswell, J. (2003). Research design qualitative, quantative and mixed methods approaches. California: Sage Pub.

Deth, J. W., \& Scarbrough, E. (1998). The impact of values (pp. 26-28). Oxford: Oxford University Press. 
Finck, C., Hansen, C., \& Jensen, J. (2003). Improving student achievement through character education. Master Thesis. Saint Xavier University, Illinois, USA

Kagitcibasi, Ç., \& Kuşdil, M. E. (2000). Value orientation of Turkish teachers and Schwartz value theory. Turkish Journal of Psychology, $15(45), 59-76$.

Kılcan, B. (2016). The role of values education course in the perceptions of teacher candidates about teaching values and teaching values. International Journal of Social Studies, 45(9), 605-618.

Kıran, Ö., \& Gül, S. (2016). An investigation of high school students' value orientations in terms of the schwartz value survey. The Journal of International Social Research, 9(47), 487-495.

Kuş, Z., Merey, Z., \& Karatekin, K. (2013). Values in primary education 4th and 5th grade social studies textbooks. Values Education Magazine, $11(25), 183-214$.

Lewis, H. (2007). A question of values: Six ways we make the personal choices that shape our lives: Axios Press.

Lickona, T. (1991). Educating for character: How our schools can teach respect and responsibility. New York: Bantam, c.

Mercader, V. (2006). Study of the ethical values of college students. University of South Florida. Graduate Theses and Dissertations.

O'Sullivan, S. (2004). Books to live by: Using children's literature for character education. The Reading Teacher, 57(7), 640-645.

Ozyurt, M., Demir, S., \& Bay, E. (2015). Evaluation of the effectiveness of the value education program developed with school-based approach. Aegean Education Journal, 6(2), 274-296.

Pala, A., \& Göğebakan, Y. D. (2019). Prospective teachers' views on ethical valuation: The case of Manisa Celal Bayar University. Cumhuriyet International Journal of Education, 8(4), 1005-1025.Available at: http://dx.doi.org/10.30703/cije.545147.

Sarı, E. (2005). Value preferences of teacher candidates: Giresun education faculty sample. Values Education Journal, 3(10), 75-90.

Sarıcı, B. S. (2013). Comparison of value trends of gazi education faculty guidance and psychological counseling department and other department students. The Journal of Academic Social Science Studies, 6(1), 1245-1261.

Schwartz, S. H. (1992). Universals in the content and structure of values: Theoretical advances and empirical tests in 20 countries. Advances in Experimental Social Psychology, 25(1), 1-65.

Serin, M., \& Buluç, B. (2014). The relationship between class teachers' perceptions of values and organizational citizenship behaviors. Kastamonu Education Journal(22), 273-290.

Uysal, F. (2008). Evaluation of character education programs. Master Thesis. Marmara University, Institute of Educational Sciences, Istanbul. Yapıc1, A., Kutlu, M., \& Bilican, F. (2012). Value orientations of teacher candidates. Electronic Journal of Social Sciences, 11 (42), $129-151$.

Appendix

Appendix-1. Values Education Program

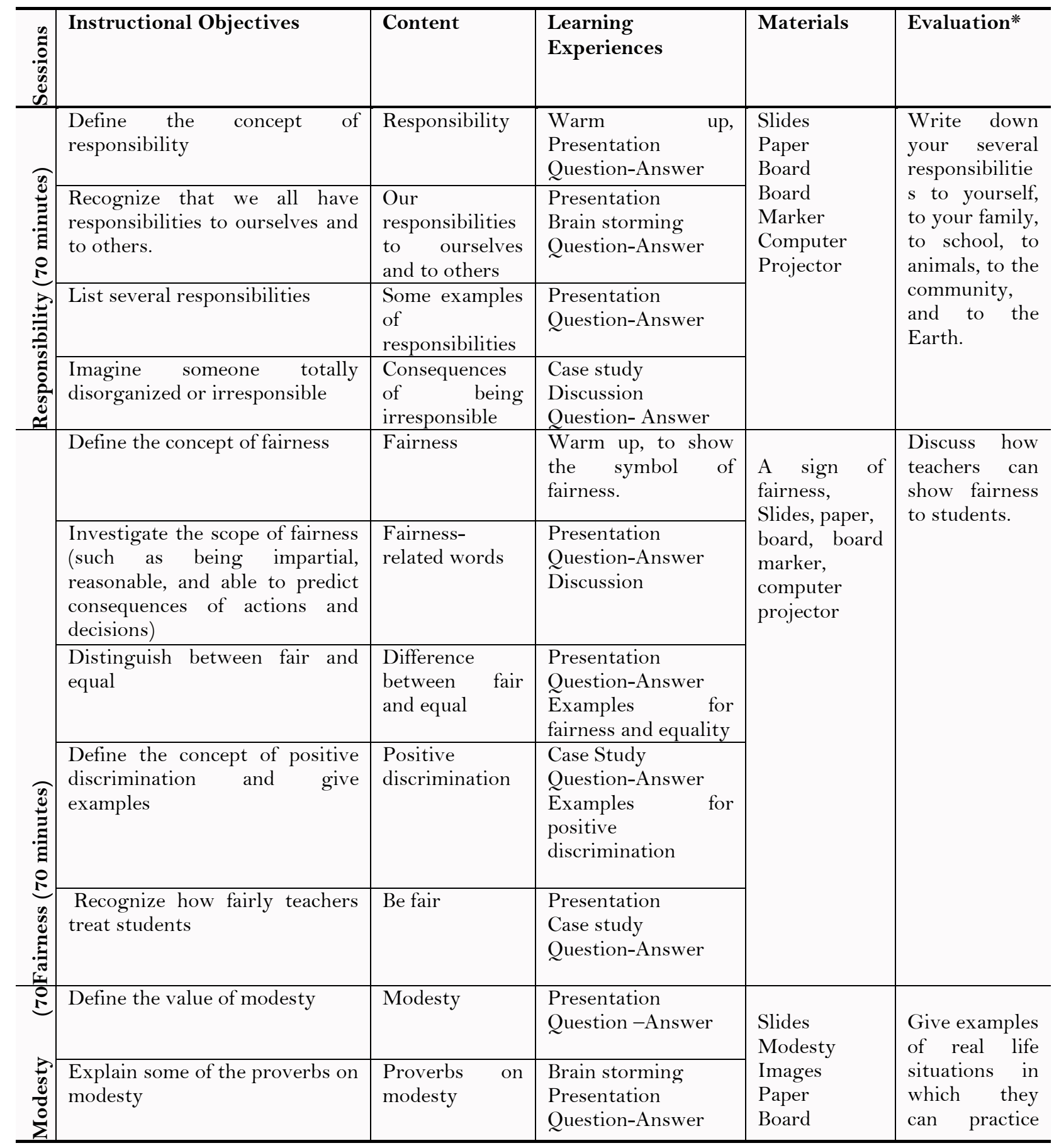




\begin{tabular}{|c|c|c|c|c|c|}
\hline & $\begin{array}{l}\text { List some of the characteristics } \\
\text { of a modest person }\end{array}$ & $\begin{array}{l}\text { Characteristics } \\
\text { of a modest } \\
\text { person }\end{array}$ & $\begin{array}{l}\text { Presentation } \\
\text { Question-Answer }\end{array}$ & \multirow[t]{2}{*}{$\begin{array}{l}\text { Board } \\
\text { Marker } \\
\text { Computer } \\
\text { Projector }\end{array}$} & \multirow[t]{2}{*}{ modesty } \\
\hline & $\begin{array}{l}\text { Talk about a story about } \\
\text { modesty }\end{array}$ & $\begin{array}{l}\text { A story } \\
\text { (www.hergenc. } \\
\text { org > ey-ulu- } \\
\text { cinar-cabuk- } \\
\text { yanima-gel) }\end{array}$ & $\begin{array}{l}\text { Presentation } \\
\text { Discussion } \\
\text { Question -Answer }\end{array}$ & & \\
\hline 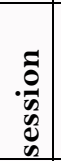 & Instructional Objectives & Content & $\begin{array}{l}\text { Learning } \\
\text { Experiences }\end{array}$ & Materials & Evaluation \\
\hline \multirow{8}{*}{ 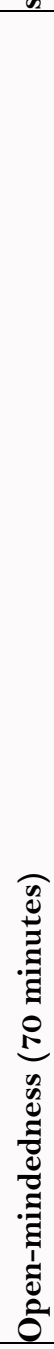 } & $\begin{array}{l}\text { Define the value of open- } \\
\text { mindedness. }\end{array}$ & $\begin{array}{l}\text { Open- } \\
\text { mindedness }\end{array}$ & $\begin{array}{l}\text { Presentation } \\
\text { Question-Answer }\end{array}$ & \multirow{8}{*}{$\begin{array}{l}\text { Slides } \\
\text { Paper } \\
\text { Board } \\
\text { Board } \\
\text { Marker } \\
\text { Computer } \\
\text { Projector }\end{array}$} & \multirow{8}{*}{$\begin{array}{l}\text { Create a two- } \\
\text { column chart } \\
\text { of } \\
\text { characteristics } \\
\text { of an open- } \\
\text { and closed- } \\
\text { minded } \\
\text { person, and } \\
\text { then, discuss } \\
\text { the } \\
\text { consequences } \\
\text { of open- and } \\
\text { closed- } \\
\text { mindedness }\end{array}$} \\
\hline & Become more open to new ideas & $\begin{array}{l}\text { Some tips will } \\
\text { help us become } \\
\text { more open to } \\
\text { new ideas }\end{array}$ & $\begin{array}{l}\text { Brain storming } \\
\text { Presentation } \\
\text { Question-Answer }\end{array}$ & & \\
\hline & Develop open-minded attitudes & $\begin{array}{l}\text { Some views on } \\
\text { how to develop } \\
\text { open- } \\
\text { mindedness }\end{array}$ & $\begin{array}{l}\text { Presentation } \\
\text { Question-Answer }\end{array}$ & & \\
\hline & $\begin{array}{l}\text { Explain the advantages of being } \\
\text { open-minded }\end{array}$ & $\begin{array}{l}\text { Advantages of } \\
\text { being open- } \\
\text { minded }\end{array}$ & $\begin{array}{l}\text { Presentation } \\
\text { Question-Answer }\end{array}$ & & \\
\hline & $\begin{array}{l}\text { List some of the characteristics } \\
\text { of an open-minded person (such } \\
\text { as resisting the urge to react } \\
\text { aggressively upon hearing } \\
\text { differing opinions, avoiding } \\
\text { speculation, etc.) }\end{array}$ & $\begin{array}{l}\text { Characteristics } \\
\text { of an open- } \\
\text { minded person }\end{array}$ & $\begin{array}{l}\text { Presentation } \\
\text { Discussion } \\
\text { Question-Answer }\end{array}$ & & \\
\hline & $\begin{array}{l}\text { Explain some of the mottos } \\
\text { about open mindedness }\end{array}$ & $\begin{array}{l}\text { Mottos (such } \\
\text { as “A mind is } \\
\text { like a } \\
\text { parachute. It } \\
\text { doesn't work if } \\
\text { it is not open.") }\end{array}$ & $\begin{array}{l}\text { Presentation } \\
\text { Question-Answer }\end{array}$ & & \\
\hline & $\begin{array}{l}\text { Respond to narrow-minded } \\
\text { people }\end{array}$ & $\begin{array}{l}\text { Narrow- } \\
\text { mindedness }\end{array}$ & $\begin{array}{l}\text { Presentation } \\
\text { Question-Answer }\end{array}$ & & \\
\hline & $\begin{array}{l}\text { List of some of the } \\
\text { characteristics of an open- } \\
\text { minded and narrow-minded } \\
\text { person }\end{array}$ & $\begin{array}{l}\text { Differences } \\
\text { between open- } \\
\text { and closed- } \\
\text { minded people }\end{array}$ & $\begin{array}{l}\text { Case study } \\
\text { Question- Answer }\end{array}$ & & \\
\hline$\stackrel{\overparen{\mathscr{D}}}{\stackrel{\mathscr{E}}{\Xi}}$ & List environmental problems & $\begin{array}{l}\text { Environmental } \\
\text { problems } \\
\text { (air pollution, } \\
\text { soil pollution, } \\
\text { climate change, } \\
\text { animal } \\
\text { extinction, } \\
\text { ecosystems, } \\
\text { energy, health, } \\
\text { waste and } \\
\text { water) }\end{array}$ & $\begin{array}{l}\text { Warm up: Our } \\
\text { world is in danger! } \\
\text { Presentation } \\
\text { Brain storming } \\
\text { Question-Answer }\end{array}$ & $\begin{array}{l}\text { Pen and } \\
\text { paper } \\
\text { Slides } \\
\text { Paper } \\
\text { Board } \\
\text { Board } \\
\text { Marker } \\
\text { Computer } \\
\text { Projector } \\
\text { Video (How } \\
\text { to Pack a } \\
\text { Waste-Free } \\
\text { Lunch) } \\
\text { https://www. } \\
\text { youtube.com/ } \\
\text { watch?v=RlG } \\
\text { JoY_EdnI }\end{array}$ & $\begin{array}{l}\text { Write a short } \\
\text { paragraph } \\
\text { about "How } \\
\text { can you help } \\
\text { our planet and } \\
\text { those who live } \\
\text { on it? }\end{array}$ \\
\hline 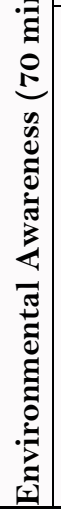 & $\begin{array}{l}\text { Work on raising awareness and } \\
\text { sensitivity to environmental } \\
\text { problems }\end{array}$ & $\begin{array}{l}\text { Solutions to } \\
\text { environmental } \\
\text { problems } \\
\text { Post signs in } \\
\text { the classroom } \\
\text { and the } \\
\text { building to } \\
\text { remind them to } \\
\text { turn out the } \\
\text { lights and to } \\
\text { turn off water } \\
\text { when not in use }\end{array}$ & $\begin{array}{l}\text { Group Discussion } \\
\text { Questions - answer }\end{array}$ & Video & $\begin{array}{l}\text { List five } \\
\text { concrete steps } \\
\text { they can take } \\
\text { to improve } \\
\text { their } \\
\text { environment. }\end{array}$ \\
\hline
\end{tabular}




\begin{tabular}{|c|c|c|c|c|c|}
\hline $\bar{s}$ & Instructional Objectives & Content & $\begin{array}{l}\text { Learning } \\
\text { Experiences }\end{array}$ & Materials & Evaluation \\
\hline \multirow{4}{*}{ 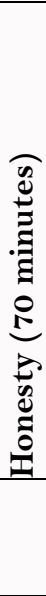 } & Define the value of honesty & $\begin{array}{l}\text { Definitions of } \\
\text { honesty }\end{array}$ & $\begin{array}{l}\text { Presentation } \\
\text { Question -Answer }\end{array}$ & \multirow{3}{*}{$\begin{array}{l}\text { Slides } \\
\text { Video } \\
\text { Paper } \\
\text { Board } \\
\text { Board } \\
\text { Marker } \\
\text { Computer } \\
\text { Projector }\end{array}$} & \multirow{3}{*}{$\begin{array}{l}\text { Give examples } \\
\text { of individual } \\
\text { behaviors } \\
\text { based on } \\
\text { honesty }\end{array}$} \\
\hline & $\begin{array}{l}\text { Explain the importance and } \\
\text { consequences of being honest }\end{array}$ & $\begin{array}{l}\text { Case studies on } \\
\text { honesty }\end{array}$ & $\begin{array}{l}\text { Brain storming } \\
\text { Presentation } \\
\text { Question-Answer }\end{array}$ & & \\
\hline & $\begin{array}{l}\text { List the characteristics of an } \\
\text { honest person }\end{array}$ & $\begin{array}{l}\text { Honest people } \\
\text { The Honest } \\
\text { Woodcutter } \\
\text { https://www.y } \\
\text { outube.com/wa } \\
\text { tch?v=vwwoot } \\
\text { av-v8 }\end{array}$ & $\begin{array}{l}\text { Presentation } \\
\text { Discussion } \\
\text { Question-Answer }\end{array}$ & & \\
\hline & $\begin{array}{l}\text { Explain some of the proverbs } \\
\text { about honesty }\end{array}$ & $\begin{array}{l}\text { Examples of } \\
\text { proverbs }\end{array}$ & $\begin{array}{l}\text { Presentation } \\
\text { Question-Answer }\end{array}$ & \multirow{5}{*}{$\begin{array}{l}\text { Slides } \\
\text { Paper } \\
\text { Board } \\
\text { Board } \\
\text { Marker } \\
\text { Computer } \\
\text { Projector }\end{array}$} & \multirow{5}{*}{$\begin{array}{lr}\text { Very } & \text { short } \\
\text { survey } & \text { to } \\
\text { evaluate } & \text { their } \\
\text { success } & \end{array}$} \\
\hline \multirow{4}{*}{ 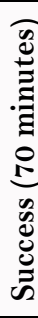 } & Define the concept of successful & Successful & $\begin{array}{l}\text { Presentation } \\
\text { Question-Answer }\end{array}$ & & \\
\hline & $\begin{array}{l}\text { Explain some of the proverbs } \\
\text { about success }\end{array}$ & $\begin{array}{l}\text { Proverbs on } \\
\text { success }\end{array}$ & \multirow{3}{*}{$\begin{array}{l}\text { Brain storming } \\
\text { Presentation } \\
\text { Question-Answer } \\
\text { Presentation } \\
\text { Question-Answer }\end{array}$} & & \\
\hline & $\begin{array}{l}\text { List some of the characteristics } \\
\text { of a successful person }\end{array}$ & $\begin{array}{l}\text { Successful } \\
\text { people }\end{array}$ & & & \\
\hline & Evaluate their level of success & & & & \\
\hline \multirow{5}{*}{ 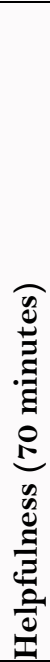 } & $\begin{array}{l}\text { Define the concept of } \\
\text { helpfulness }\end{array}$ & Helpfulness & $\begin{array}{l}\text { Warm up } \\
\text { Brain storming } \\
\text { Presentation } \\
\text { Question-Answer }\end{array}$ & \multirow{5}{*}{$\begin{array}{l}\text { Slides } \\
\text { Paper } \\
\text { Board } \\
\text { Board } \\
\text { Marker } \\
\text { Computer } \\
\text { Projector }\end{array}$} & \multirow[t]{5}{*}{$\begin{array}{l}\text { List a variety } \\
\text { of ways one } \\
\text { can be helpful }\end{array}$} \\
\hline & $\begin{array}{l}\text { Explain some of the quotes on } \\
\text { helpfulness }\end{array}$ & $\begin{array}{lr}\text { Meaning } & \text { of } \\
\text { quotations } & \text { on } \\
\text { helpfulness } & \end{array}$ & $\begin{array}{l}\text { Presentation } \\
\text { Question-Answer } \\
\text { the quotation sheet }\end{array}$ & & \\
\hline & $\begin{array}{l}\text { Discuss the importance of being } \\
\text { helpful }\end{array}$ & Helpfulness & $\begin{array}{l}\text { Presentation } \\
\text { Role-playing } \\
\text { Question-Answer } \\
\text { Discussion } \\
\end{array}$ & & \\
\hline & $\begin{array}{l}\text { Identify how they can be helpful } \\
\text { at home and in school }\end{array}$ & $\begin{array}{l}\text { Ways of } \\
\text { Helpfulness }\end{array}$ & $\begin{array}{l}\text { Presentation } \\
\text { Question-Answer }\end{array}$ & & \\
\hline & Talk about the joy of helping & $\begin{array}{l}\text { Association } \\
\text { with happiness } \\
\text { and helpfulness }\end{array}$ & $\begin{array}{l}\text { Presentation } \\
\text { Question-Answer }\end{array}$ & & \\
\hline
\end{tabular}

